\title{
Information Marketing to the Library Users
}

\author{
Mukmin Suprayogi \\ Library and Information Science Department \\ Syarif Hidayatullah State Islamic University, Jakarta, Indonesia \\ msyogi@uinjkt.ac.id
}

\begin{abstract}
Library as a work unit within the parent institution has a strategic role in providing information services to its users. It takes a variety of tricks for the library to be in demand by its users. By understanding the basic principles of marketing commonly used in the business world, it is hoped that libraries will be able to improve service even better. Librarians need to find the right pattern in realizing better service, Considering that the library offers an information service. Information as a product of a library service means that data is processed into a form that has meaning to the users and has a real and perceived value for the current decision or future decision.
\end{abstract}

Keywords-Information; marketing; library Service; translation book

\section{INTRODUCTION}

The marketing term for the first time was written by Theodore Levitt in his article entitled "Marketing Myopia". Writing in Harvard Business Review 1960, Levitt realizes the business world that marketing is regarded as 'kid's onion'. According to Levitt ,. Sales focus: we like sellers' wishes, marketing is focused on the needs of buyers. Sales are preoccupied with the seller's interest in turning products and services into cash, while marketing is preoccupied with the idea of satisfying customer needs through products and services, and a myriad of tools related to manufacture, delivery and end use. products and services.

Actually before Levit [1], there was another incredible marketing expert echoing in the business world, Peter $\mathrm{F}$ Drucker [2] who had been far ahead of his group in almost every point of management theory for half a century ago. According to Drucker, the business purpose is only one legitimate definition for Creating Customers. Markets are not created by "gods", natural forces or economic forces, but by the business itself. After all, it's a business act that creates a customer. And "customer determines business existence". Marketing is a unique function of business that sets it apart from other businesses. The fact shows that a business stands apart from an organization that markets a product or service, " Any organization that gets its performance through marketing a product or service, is a business'.

This paper can not be further examined about the business or marketing world, but only using the basic concept of marketing in further observing the activities of services in the library, understanding: technical information, marketing services: create unreal, variety, production and simultaneous consumption, marketing information service tricks, evidence management, and equalize and demand.

\section{LIBRARY SERVICES}

George Mukdisi [3], in his work The Rise of Colleges: Institution of learning in Islam and the West, says there are six terms used in an integrated way to describe libraries. The first three conditions are bayt (room / space), khizanah (cupboard), and dar (home); and the three second terms of wisdom (policy), 'ilm (science) and poles (books). These words when combined will form seven concepts that describe the form of the library, namely: bait al-hikmah, khizanah alhikmah, dar al-hikmah, dar al-'ilm, dar al-pole, bayt al-pole and khizanah al -the pole. This fact shows that the combination of all these has been used, is very often to be interchangeable.

At that time, the most famous Muslim library was Bayt al-Hikmah, a joint research institute, library and translation bureau, found by Caliph Abbasiah, Harun Al-Rashid, in Baghdad in $830 \mathrm{AD}$

Many of the translation books of the language are not Arabic such as Greek and Sankrit, which sprang up this library, is listed in Fransham's work by Ibn-Al-Nadim and Kashf by Haj Khalifah. The son of Aaron Al-Rashid, Caliph Ma'mun Al-Rashid, is said to have employed the first Muslim scholars, to translate Aristotle's works into Arabic. Alkindi himself wrote nearly three hundred books on various medical problems, philosophy to music stored in Bayt al-Hikmah. Ma'mun hired translators and, to stimulate their efforts to endorse and sign every translation.

Later, especially around the 1980s, a Pakistani Muslim futurology, in his well-known work, "Information and the Muslim World: a Strategy for the Twenty-first Century" [4], dedicated itself to the development of information services in developing countries. Pauline Atherton [5], in her monumental work entitled "Handbook for Information System and Services". Sardar reminds us of the importance of building the civilization of the Muslim world through a scholarly repertoire of Muslim traditions, while Atherton developed a number of information services to serve as a reference in building scientific Library, Documentation and Information (Pusdokinfo) scientifically in developing countries. At least three variables owned by Pusdokinfo institutions, namely: function, service and product.

From both information experts, Sardar and Atherton are 
mentioned at least 7 functions of Pusdikinfo, namely: collection, processing, storage, rediscovery, dissemination, publication and reproduction and information making.

In terms of service, Pusdokinfo institutions should do a number of things directly related to the needs of users, such as: consultation and advice, answering questions, referencing, tracking information, serving visitors, organizing seminars and conferences, conducting research, serving translations, preparing progress reports, literature and critical compilations.

Equally important, Pusdokinfo products should be clear, among other things: handbooks, bibliography, data sheets, bulletin actual information, magazines, abstracts, indexes, films, directories, translation works, thesaurus, recommendations, additional list of collections and proceedings.

Products and services can be tailored to the current conditions, and can be further developed, such as: VCD / DVD, Audio Visual, Internet, and other information technology products services so as to create more up to date Pusdokinfo institutions such as Institutional Repository, Multimedia Library, Digital Library, Virtual Library, and the like.

\section{INFORMATION PHENOMENA}

If a document is lying or scattered in a room or building, can it be considered information? Of course it's hard to say, can not it? This will then create an uncertain state of information that even leads to entropy, even that information will be useless and unused. When found or tracked, it will turn into something of value. So, the meaning is not on the document, but on its usefulness. In the context of information, we need to assume that a document does not contain any information for an illiterate person. Similarly, if it is written in an unfamiliar language, then it becomes an obsolete paper. Therefore, "the meaning of information can not be understood without reference to its social function". As a phenomenon, in view of information, we can identify into 6 components, namely: Absolute, Substitutional, Philosophical, Subjective, Objective and Cultural.

By analogy as a "big tree," these six components can be described as follows: the first branch of the information tree refers to the type of information that is considered true and absolute, and no doubt the information contained, for example the Qur'an and Al Hadith. The second branch refers to cases when the concept of information is sometimes superseded by "communication". The third branch deals with concepts related to information with science and policy (philosophical). The fourth branch connects information with human feelings and emotions, which, in so far as they are concerned, information depends on the human (Subjective). The fifth branch refers to the logical character of certain types of information (objective), such as: mathematical logic and informatics. And finally, the sixth branches emphasise the information culture dimension, which is related to the aspects of its benefits and usefulness to the Muslim (cultural) community.

In an operational context, information means that data is processed into a form that has meaning to the recipient and has a real and felt value for the current decision or future decision. While the shape, can be in alphabetic, numeric, or alphanumeric form, as well as symbols or codes. In the context of libraries, the forms and types of information vary widely from bibliographic information, ideas, concepts, theories, analysis, theses, antithesis, and syntheses in various scholarships that lead to the "third branch of scholarship" philosophical or relative (truth, as far as the reach of human thought). The problem is whether the concept of information contained in the Pusdokinfo concept can be captured and operated within the Pusdokinfo framework, or can be used as a "library service" by Librarians and Information Experts?

\section{CHARACTERISTICS OF SERVICES}

Although the service industry is essentially highly heterogeneous (from beauty salons, child care, schools, hospitals, libraries, museums, to electrical appliances), there are several service characteristics that can be generalised. Three of the most important characteristics can be described after we know what the definition of Services is. Many definitions of Services. A number of experts define services as follows:

Services are any actions or activities that one party may offer to other parties. It is basically intangible and does not result in any ownership. Production Services may be related to a physical product (goods) or disengaged altogether. [6].

Goods are a tangible object that can be created and sold or used after a certain time interval. Service is Intangible, and Perishable (services that may not be stored as ready-to-sell or consume when required) Services are created and consumed simultaneously [7].

Because of that condition, the characteristics of services can be distinguished as follows:

1. Intangible (intangible or unreal). Thus, services cannot be seen or felt before purchased by the buyer.

2. Non-standardise or Variability (Non-standard). The quality of services is difficult to standardise because it is strongly influenced by the people giving their services.

3. Inseparable (Simultaneous or simultaneous in production and consumption). Services are usually produced and consumed at the same time. If the goods are manufactured first sold, but services are usually sold first produced and consumed at the same time. Because of this nature, services can not be stored in inventory (Non-Inventory).

A good is an object or a tool. While Services is an action, performance, and effort. When an item is purchased, something real is gained: something that can be seen, touched, smelled, or worn. However, when services are purchased, there is generally not something that seems real. Once we have the money we spend, but no additional clothes that can be hung in our closet, and there is nothing we can have. This also happens to library services, when we provide borrowing services, reading room services or referral services or references, none of which library members have (depending on whether the actions, performance, and endeavor of those 
serving are appropriate or outside the professional standard).

Most of the market offerings are a mixture of real and unreal elements. The thing that determines the classification of some goods or services is whether the core of what is bought / exchanged is real or unreal. Example: Bibliographic information becomes real because a number of sheets of paper are written and we give to consumers or users of the library, but becomes unreal if it made haphazardly and has no relevance / usefulness to the receiver / consumer, because it can not be used anything (remember the meaning information because of its usefulness). Other examples: In restaurants, food handouts, preparations and services, after-meal cleaning (or mixing of them) is done for the consumer by other parties. In other word, it can be described that the restaurant industry is a service industry, although there is something real related, for example: building, interior decoration, kitchen equipment, and food.

The concept of unreality has two meanings, and both mean it poses a challenge in the field of marketing: it can not be touched or felt and can not be formulated or reached easily.Regarding to the marketing issues that are not real, in general more attention by service marketers rather than marketers of goods, because service marketers try hard how to make it real.

\section{VARIETY}

The service industry tends to vary, depending on whether the industry is "human-based" or "tool- based". That is, more dominant human components involved in providing services than other components. One implication of this difference is that the "results" of human-based service delivery tend to be less standardized and uniform than the results of service delivery on the basis of tools or producers of goods. Example: Typing catalogs manually, then replaced by using a computer, of course the results are different.

\section{PROdUCTION AND CONSUMPTION SIMULTANEOUSLY}

Services are usually produced and consumed at the same time. A college professor produces educational services, while students consume them. Phone companies produce phones, while phone users consume them. Baby care providers produce babysitting services, while children and parents consume them.

In general, the goods are produced, then sold, then consumed. On the other hand, services are usually sold first, then generated and consumed simultaneously. Concurrent production and consumption means that service providers often physically present something when consumption occurs. Example: a lecturer presents when there are students, a doctor presents when there is a patient and borrowing books executed when there is a library member who borrow it.

The important thing to know about the presence of service providers is how the distribution of services in marketing science emphasize on the distribution of goods, where and when customers want them to be distributed on the "right place" and "right time". Services, too, often need to be channeled in the "right way". Example: how does the Librarian or Information Officer, Lecturer, Lawyer, behave when a customer arrives, can it influence future customer decisions, whether to subscribe or quit at the first meeting?

\section{INFORMATION MARKETING INFORMATION TRICKS}

\section{A. Internal Marketing}

Internal marketing means applying marketing philosophies and practices to those who serve external servants, so that (I) the people most likely to be employed and retained; (2) they will do the work they are most likely to do. More specifically, internal marketing means viewing employees as internal customers, viewing work as an internal product, and striving to design these products to meet customer needs well. In short, successful managers must first sell their work to employees before it can sell its services to customers.

\section{B. Imaging Services}

The purpose of marketing is to bring together the similarity between what the customer wants to buy and what the company wants to sell, so that the service as far as possible meets the individual customer's wishes. Example: A person who wants to be imaged as a particular scientist, expert, or expert if his/her photographs or films are usually backed up by "a row of books", or done in a library. That is, the book and a series of books that "portray" or 'portrait' that gives the impression to the public, that he is as a smart person (not drinking herbs or beer). Those things can also be to other professions, such as librarians or Pusdokinfo officers, to remove the stigma that librarians are librarians who wear thick glasses, dressed shabby with a stack of books. As a result, the librarian is reluctant to come to the library, or ask much less discuss with the librarian.

\section{Managing Evidence}

Goods are generally easier to evaluate than services. The nature of services is not real, encouraging customers to pay attention to the real things related to services as a guide to the nature and quality of services. The basic responsibility for the service marketer is to manage these real things, so that the proper symbol of the service can be properly delivered. Product marketing tends to put the first emphasis on creating abstract relationships. On the other hand, service marketers must focus on improving on different "realities" through manipulation of concrete clues. The management of evidence must take precedence by service marketers [1].

There are a number of ways in which service marketers can manage evidence, as shown below.

\section{Physical Services Environment}

Physical state is related to purchased services, in 
general giving an important opportunity to tell the "real" about the services provided. Service marketers often control specific circumstances, have experience in distributing the services they produce. For example, in this physical management, such as: parking lot, building, arrangement of living room / interior design, fresh atmosphere, lighting, table and chairs arrangement, room cleanliness, and the like.

\section{Appearance of Service Provider}

The appearance of service providers is another real thing that can be managed. Example: a doctor's uniform, with a white outfit. Or, the bank teller, who is always neat, friendly, polite, with a cheerful and pleasant welcome, and always ready to help.

\section{Pricing of Services}

It is well known that there is a tendency for customers to use product prices as an indicator of quality. It should be noted that setting the right price / exchange value is very important, in a condition where there is a high enough personal risk if purchasing a service of inferior quality. Lawyers, accountants, consultants, seminar speakers, even hairdressers will not set the price too low as it signifies the quality of their services. In short, a price can build trust, price is a clue.

\section{Linking Service Marketing to Goods Prices}

Sometimes the credibility of the Service quality can be lifted by distributing it through a marketing organisation of goods that already has credibility. Example: The library gives $10 \%$ - $20 \%$ special rebate for its members when shopping for books or stationery at Gramedia Bookstore, Gunung Agung, or Kharisma by showing a Library member card, this may be one of the interesting tips for people to become a library member, because its clear benefits and usefulness [8].

\section{EQUALIZE INVENTORY AND DEMAND}

As mentioned earlier, the unreal state has two dimensions. Unforeseeable or unreachable conditions will benefit the marketing worker if services are made more "touchable" and more accessible. All are related to making business more real. Since services are performance, services can not be inventoried. This is a significant fact of life in managing services, because peak demand can not be accommodated by taking goods off a shelf. Service marketers in delivering supply and demand well, may try to reshape the demand and supply patterns of those services.

All elements of the marketing mix are potentially available to bring demand more in line with inventory. Example: a flight, which uses price incentives to encourage tourists to fly in the morning and late at night. This can also be done by providing library services with additional incentives book loans for users as a service user who is disciplined in borrowing and returning books in a timely manner.

Another option available to service marketers is to try to change inventory capacity to better meet demand patterns in the following ways: (a) Using part-time employees and only doing important tasks during times of great demand (such cases are used by PT Pos, which uses retired students in the fasting month, especially before Lebaran); (b) Training employees to do multiple tasks, so they can switch tasks to other tasks when there is a demand, give the current trend forward with multi- skill; (c) Replacing equipment for human labor to make the service system is more productive, such as the use of ATM in banks, the library can use the tool as a means of circulation.

\section{CONCLUSION}

Services are different from goods in some important ways, let alone information services, so these differences provide special challenges to information and library service managers, especially in marketing them. The importance of the service sector in today's era becomes real for all of us, therefore we need to learn more, especially to recognise the characteristics of services that have implications in marketing. Services are more invisible than appear, non-standard, and are produced simultaneously in comparison with goods. The important of service marketing is how to take advantage of internal marketers, service imaging, evidence management, make services real, and balance inventory and demand.

\section{REFERENCES}

[1] Theodore Levitt, "Marketing Myopia," in Managing with the Gurus. Carol Kennedy (1999) “Managing With The Gurus"., Jakarta: Elex Media Komputindo, 1960.

[2] P. F. Drucker, The Practice o.f Management. New York: Harper \& Row, 1954.

[3] George Makdisi, The Rise of Colleges: Institutions of Learning in Islam and the West. Endinburgh: Universiti Press, 1981.

[4] Ziauddin Sardar, Information and the Muslim World: a Strategy for the Twenty-first Century. London, New York: Manzell Publishing, 1988.

[5] P. Atherton, Sistem dan Pelayanan Informasi. Jakarta: Arga Kencana Abadi, 1985.

[6] P. Kotler, Manajemen Pemasaran:Analisis, Perencanaan, Implementasi, dan Pengendalian. Jakarta: Salemba Empat, 1994.

[7] Robert G. Murdick, Service Operation Management. Boston: Allyn and Bacorn, 1990.

[8] Leomard L. Berry, "Service Marketing is Different," Marketing Classics, p. 1991. 